\title{
A Method to Calculate Corrective Coefficients for the Valuation of Land Rental Payments
}

Irina Aleksandrovna Astrakhantseva*

Ekaterina Vyacheslavovna Balandina**

\section{Introduction}

The leasing of state property, as well as property of the subjects of the Russian Federation (SORF) and municipalities, is quite common in Russian land-use practice. The provision of land for rent is one of the most common sources to replenish municipalities' budgets (Tax Code of the Russian Federation). At the same time, it is one of the ways to effectively manage property that is temporarily unused or used inefficiently. The amount of the rental fee depends on the value of the land, its area, the land tax rates, as well as the value of the corrective coefficients.

The purpose of this study is to develop an economically feasible methodology to calculate corrective coefficients needed to further justify the rental fee for land use.

\section{Methodology Description}

Currently, there are two main ways to calculate rental fees for land use: the calculation can be made either for each plot separately or for a set of plots combined into several groups according to a number of identifying characteristics. Calculating individual rental fees entails the objective consideration of all typical features and characteristics of a particular plot, resulting in a fair rent fee for the use of the facilities. However, in the modern context, performing such a calculation

\footnotetext{
* Irina Aleksandrovna Astrakhantseva - Professor, Ivanovo State University of Chemistry and Technology, Department of Information Technology and Digital Economy, e-mail: i.astrakhantseva@mail.ru.

** Ekaterina Vyacheslavovna Balandina - MSc, Ivanovo State University of Chemistry and Technology, Department of Information Technology and Digital Economy, e-mail: balandina_ev@bk.ru.
} 
seems impossible due to the considerable time and labor costs required for its implementation because of the large number of plots of land located within the territory. For this reason, municipalities tend to turn to a second option for calculating rental fees. For these purposes, plots of land are grouped in a special way. The basis for the grouping, as a rule, is the category of the land and the options for its permitted use.

The rental fee calculation is, as a rule, a product of the land-cadastral-value-specific indicator, its area and the corrective coefficient, for which there is no unified calculation methodology (On basic principles... 2009).

$$
\mathrm{RF}=\mathrm{LCVSI} \times \mathrm{S} \times \text { Ccor }
$$

where: RF is the annual rental fee in rubles. LCVSI is the land-cadastral-value-specific indicator in ruble/sq. $\mathrm{m}$. $\mathrm{S}$ is the land area in sq. $\mathrm{m}$. Ccor is the corrective coefficient, established and differentiated depending on the permitted land use.

The corrective coefficient calculation is based on the same principles as the process of making adjustments for basic pricing factors to the base (market) price of real estate objects or rental fees for their use when evaluating real estate according to the sales comparison method (Petrov 2007). To calculate the rental fee corrective coefficient, the following formula is proposed:

$$
\text { Ccor }=(\text { Minimum coefficient }+ \text { Rent allowance }) \mathrm{x} \mathrm{K}_{1} \times \mathrm{K}_{2} \times \mathrm{K}_{3} \times \mathrm{K}_{\mathrm{i}}
$$

where: minimum coefficient is the land tax rate (determined by regulations of the representative bodies of the municipalities within the limits set forth in Article 394 of Chapter 31 Land Tax of the Tax Code of the Russian Federation). Thus, the value of the minimum coefficient for each group of lands is set at the amount of tax established for this group of lands in accordance with the Tax Code of the Russian Federation. $\mathrm{K}_{1}$ is the degree of influence of an entrepreneurial activity's result on the area's budget revenues. $\mathrm{K}_{2}$ is the degree of negative impact on the state of the land. $\mathrm{K}_{3}$ is the degree of influence on the creation of the area's social attractiveness. $\mathrm{K}_{\mathrm{i}}$ is the degree of investment attractiveness. Rent allowance is calculated using the following formula:

Rent allowance $=$ Degree of land use *

(Maximum coefficient - Minimum coefficient)

where: maximum coefficient stands for double the rate of the land tax. Minimum coefficient is the land tax rate. The degree of land use is the degree estimated using the weighted risk assessment method. In the practice of evaluating real estate objects and the rental fee for their use, one must recognize the necessity to take into account pricing factors that are characteristic of a particular SORF property and affect the value being determined (Telman 2005). Similarly, to calculate the amount of correction coefficients used in establishing the rental fee for plots 
being leased, it is necessary to form a list of factors that affect the nature of land use and which are reflected in the amount of the correction coefficient and, accordingly, in the amount of the rental fee. Given the analysis of the existing practice of land plot evaluation (Novitsky et al. 2015), as well as studies of the macro and microeconomic parameters, the following set of pricing factors is suggested, the influence of which takes into account such indicators as "the degree of land use" (Astrakhantseva 2016):

I. General economic and political factors (the influence of federal laws and the regulations of the SORF; compliance of activities carried out on the land with priority areas of state policy).

II. Factors of the municipality's socio-economic status (trends in the development of the economy and production potential; investment attractiveness; city-planning policy; goals and directions of development).

III. Factors of profitability (level of market development; profitability of organizations corresponding to the permitted use of land; availability of demand for the results of activities carried out on the land).

IV. Physical characteristics (availability of engineering infrastructure; transport accessibility; land topology).

V. Factors related to the geographical location of the land (remoteness from the regional center; the influence of natural and climatic conditions; environmental factors; remoteness from water bodies).

The procedure for calculating the corrective coefficients applied in determining the rental fee amount for land is as follows:

1. Justification of additional coefficients $\mathrm{K} 1, \mathrm{~K} 2, \mathrm{~K} 3$.

2. Justification of choice and number of factors of the degree of land use.

3. Calculation of the degree of land use.

4. Calculation of rent allowance.

5. Determination of corrective coefficients.

Calculating coefficients $\mathrm{K} 1, \mathrm{~K} 2$ and $\mathrm{K} 3$ is aimed at determining the degree of influence of each factor on the amount of the rental fee. The coefficients are calculated using the hierarchy analysis method, where the factors that have the greatest influence on the performance of the analyzed activity, and that depend mainly on the type of permitted land use, are taken as the comparison criteria (Balandina and Astrakhantseva 2016).

The calculation of the investment attractiveness coefficient is based on the ten main factors presented in Table 1 being taken into account. Since a large number of parameters were chosen for the analysis of the investment attractiveness of land, with a degree of impact that is difficult to quantify, it was decided to calculate this coefficient using the directional qualitative adjustments method, taking into account the direction of each factor's impact on the activities carried out on the 
land (Veig 2009). If the investment attractiveness, as related to any parameter, is positively or negatively influenced, the parameter is assigned a score of +1 or -1 , respectively. Parameters without influence are assigned a score of 0.

$$
\mathrm{K}_{\mathrm{i}}=1+\frac{\sum n_{i}}{10}
$$

where $\mathrm{K}_{\mathrm{i}}$ is the investment attractiveness coefficient and $n_{\mathrm{i}}$ are the values of the investment attractiveness parameters.

Table 1. Investment attractiveness calculation pattern

\begin{tabular}{|c|l|c|}
\hline No. & Parameter & Parameter score \\
\hline 1 & Financial attractiveness & \\
\hline 2 & Territorial attractiveness & \\
\hline 3 & Attractiveness of products/services & \\
\hline 4 & Personnel attractiveness & \\
\hline 5 & Innovative attractiveness & \\
\hline 6 & Environmental attractiveness & \\
\hline 7 & Social attractiveness & \\
\hline 8 & Information attractiveness & \\
\hline 9 & Attractiveness of corporate culture & \\
\hline 10 & Level of risk of the industry & \\
\hline Total score & \\
\hline \multicolumn{2}{|l|}{ The maximum score (modulo) $\left(\mathrm{n}_{\mathrm{i}}\right)$} & \\
\hline Adjustment to the investment attractiveness $\left(\mathrm{K}_{\mathrm{i}}\right)$ & \\
\hline
\end{tabular}

Source: own elaboration

The degree of land use, as related to the impact of the above-mentioned factors, is calculated by the weighted assessment method using the following pattern:

Table 2. Assessment of the degree of land use

\begin{tabular}{|l|l|l|l|l|l|l|l|l|l|l|}
\hline Name and type of factors & 1 & 2 & 3 & 4 & 5 & 6 & 7 & 8 & 9 & 10 \\
\hline I. General economic and political factors & & & & & & & & & & \\
\hline $\begin{array}{l}\text { 1. The influence of federal laws and the } \\
\text { regulations of the subject of the Rus- } \\
\text { sian Federation }\end{array}$ & & & & & & & & & & \\
\hline $\begin{array}{l}\text { 2. Compliance of activities carried out on } \\
\text { the land with priority areas of state policy }\end{array}$ & & & & & & & & & & \\
\hline $\begin{array}{l}\text { II. Factors of the municipality's socio- } \\
\text {-economic status }\end{array}$ & & & & & & & & & & \\
\hline $\begin{array}{l}\text { 1. Trends in the development of the } \\
\text { economy in the area }\end{array}$ & & & & & & & & & & \\
\hline 2. Production potential of the area & & & & & & & & & & \\
\hline
\end{tabular}




\begin{tabular}{|c|c|c|c|c|c|c|c|c|c|c|}
\hline Name and type of factors & 1 & 2 & 3 & 4 & 5 & 6 & 7 & 8 & 9 & 10 \\
\hline \multicolumn{11}{|l|}{$\begin{array}{l}\text { 3. Conditions for economic growth of } \\
\text { the area }\end{array}$} \\
\hline \multicolumn{11}{|l|}{ 4. City-planning policy } \\
\hline \multicolumn{11}{|l|}{$\begin{array}{l}\text { 5. Compliance of activities with the } \\
\text { main directions of development }\end{array}$} \\
\hline \multicolumn{11}{|l|}{ III. Factors of profitability } \\
\hline \multicolumn{11}{|l|}{$\begin{array}{l}\text { 1. Level of market development cor- } \\
\text { responding to the permitted land use }\end{array}$} \\
\hline \multicolumn{11}{|l|}{ 2. Average profitability of organizations } \\
\hline \multicolumn{11}{|l|}{$\begin{array}{l}\text { 3. Availability of demand for the re- } \\
\text { sults of activities }\end{array}$} \\
\hline \multicolumn{11}{|l|}{ IV. Physical characteristics } \\
\hline \multicolumn{11}{|l|}{$\begin{array}{l}\text { 1. Existence and availability of engine- } \\
\text { ering infrastructure }\end{array}$} \\
\hline \multicolumn{11}{|l|}{$\begin{array}{l}\text { 2. Transport accessibility, remoteness } \\
\text { from main highways }\end{array}$} \\
\hline \multicolumn{11}{|l|}{ 3. Land topology } \\
\hline \multicolumn{11}{|l|}{$\begin{array}{l}\text { V. Factors related to the geographical lo- } \\
\text { cation of the land }\end{array}$} \\
\hline \multicolumn{11}{|l|}{ 1. Remoteness from the regional center } \\
\hline \multicolumn{11}{|l|}{$\begin{array}{l}\text { 2. Influence of natural and climatic } \\
\text { conditions }\end{array}$} \\
\hline \multicolumn{11}{|l|}{ 3. Environmental factors } \\
\hline \multicolumn{11}{|l|}{ 4. Remoteness from water bodies } \\
\hline \multicolumn{11}{|l|}{$\begin{array}{l}\text { Number of observations corresponding } \\
\text { to each land use degree }\end{array}$} \\
\hline \multicolumn{11}{|l|}{ Weighted total } \\
\hline \multicolumn{11}{|l|}{ The final value of the land use degree } \\
\hline \multicolumn{11}{|l|}{ Number of factors } \\
\hline \multicolumn{11}{|l|}{ Maximum score } \\
\hline The final value of the land use degree, $\%$ & & & & & & & & & & \\
\hline
\end{tabular}

Source: own elaboration

The estimation of the degree of land use for each factor is determined by the method of weighted estimation with the help of a ranking scale, the application of which is quite widespread and is described in detail in many fields of scientific research (Dubina 2006). The scale used to estimate the land use degree is presented in the following table. 
Table 3. Factor assessment criteria ranking scale

\begin{tabular}{|c|l|}
\hline $\begin{array}{c}\text { Degree of } \\
\text { influence }\end{array}$ & Risk level characteristic \\
\hline 1 & Influence of factor is minimal \\
\hline 2 & Influence of factor is mild, with a slight impact on financial and economic activities \\
\hline 3 & $\begin{array}{l}\text { The selected factor can influence financial and economic activities; however, this } \\
\text { influence is not significant }\end{array}$ \\
\hline 4 & $\begin{array}{l}\text { Influence of the selected factor is below average. The impact of the factor is signi- } \\
\text { ficant, but not crucial for financial and economic activities }\end{array}$ \\
\hline 5 & $\begin{array}{l}\text { Influence of the factor is average; there is a large number of other factors affecting } \\
\text { financial and economic activities }\end{array}$ \\
\hline 6 & $\begin{array}{l}\text { Influence of the selected factor is above average; the influence of other factors is } \\
\text { limited }\end{array}$ \\
\hline 7 & $\begin{array}{l}\text { Influence of the selected factor is significant; the influence of other factors on fi- } \\
\text { nancial and economic activities is possible }\end{array}$ \\
\hline 8 & $\begin{array}{l}\text { Dependence of activities on the state and the level of influence of the selected } \\
\text { factor are significant; the influence of other factors is limited }\end{array}$ \\
\hline 9 & $\begin{array}{l}\text { Dependence on the state and the level of influence of the factor is crucial for finan- } \\
\text { cial and economic activities; the influence of other factors is minimal }\end{array}$ \\
\hline 10 & Absolute dependence on the state and the level of influence of the selected factor \\
\hline
\end{tabular}

Source: own elaborations

After determining the land use degree as related to all factors, the number of observations for each column is calculated using the formula:

$$
\mathrm{WT}_{\mathrm{i}}=\mathrm{n} \times \mathrm{N}_{\mathrm{i}},
$$

where $\mathrm{WT}_{\mathrm{i}}$ is the weighted total for each degree of land use, $\mathrm{n}$ is the number of observations corresponding to each degree of use and $\mathrm{N}_{\mathrm{i}}$ is the sequence number of the land use degree, which according to the above table can be from 1 to 10 .

At the next stage, the final value of the degree of land use is calculated by summing of all weighted totals for each level of use. The maximum score is equal to the product of the number of analyzed factors and the maximum degree of use. In this case, 17 factors are selected with the maximum possible degree of land use equal to 10. Thus, the maximum score is 170 . The degree of land use is calculated as the ratio of the final value of the degree of land use to the maximum score. At the final stage, the corrective coefficient is calculated using Formula (2).

\section{Methodology Implementation}

The authors calculated the corrective coefficients used in determining the rental fees for land use in Ivanovo. For this purpose, more than 100 types of permitted land use were analyzed. The values of the calculated coefficients are presented in the following diagram. 
Figure 1. Values of the corrective coefficients in Ivanovo

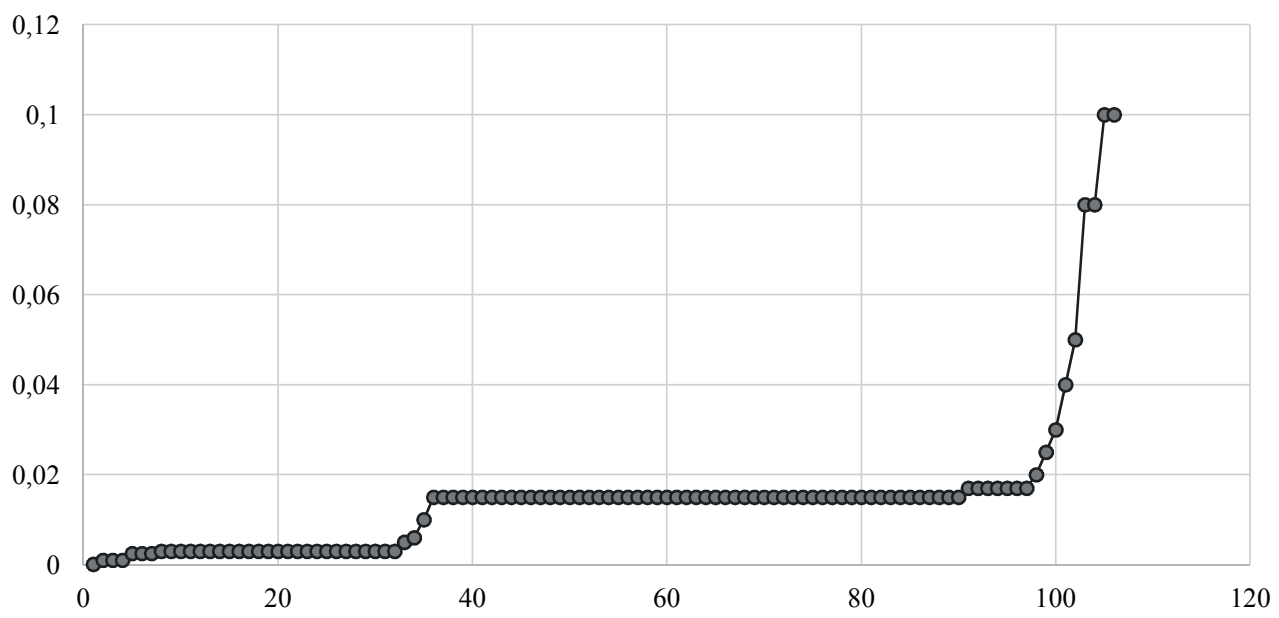

Source: own research based on calculations performed according to the author's methodology

As can be seen in the diagram, all coefficient values can be conditionally divided into three groups. For the overwhelming majority of permitted use types (sector II on the diagram), the corrective coefficient value is 0.015 , which corresponds to the average coefficient value in Ivanovo ( $\left.\bar{C}_{\text {cor }}\right)$. For the first group of plots of land, the value of the coefficients is below average. This group mainly includes facilities intended for residential development, horticulture, and agriculture, that is, facilities whose profitability is currently at the minimum level. The last group (sector III) includes land intended for the most profitable types of activities (for trade and catering facilities, transport services, and service sector facilities). The values of the coefficients for this group of plots of land are at an above average level, which implies a higher amount of rental fees for the use of these plots.

The authors of the methodology carried out the analysis of the change in the amount of rental fees for the use of plots of land located in Ivanovo before and after the methodology approbation. In Figure 2, the columns of the first row reflect the average value of the previously established rental fees for $1 \mathrm{sq}$. $\mathrm{m}$. of land. The columns of the second row reflect the average value of rental fees calculated using the methodology developed. It can be noted that for a number of permitted land use types (PUT), the amount of the rental fee has changed (Leifer 2014). Regarding land which is part of a dacha, which belongs to horticultural and gardening associations (PUT-4), land intended for the placement of hotels (PUT-6) and for the placement of production and administrative buildings (PUT-9), the average value of the rental fee for $1 \mathrm{sq}$. $\mathrm{m}$. of land has decreased, which is due to the poor development of these activities in the city and, consequently, the need for their support by the municipality. 
Figure 2. Comparison of average rental fees in Ivanovo

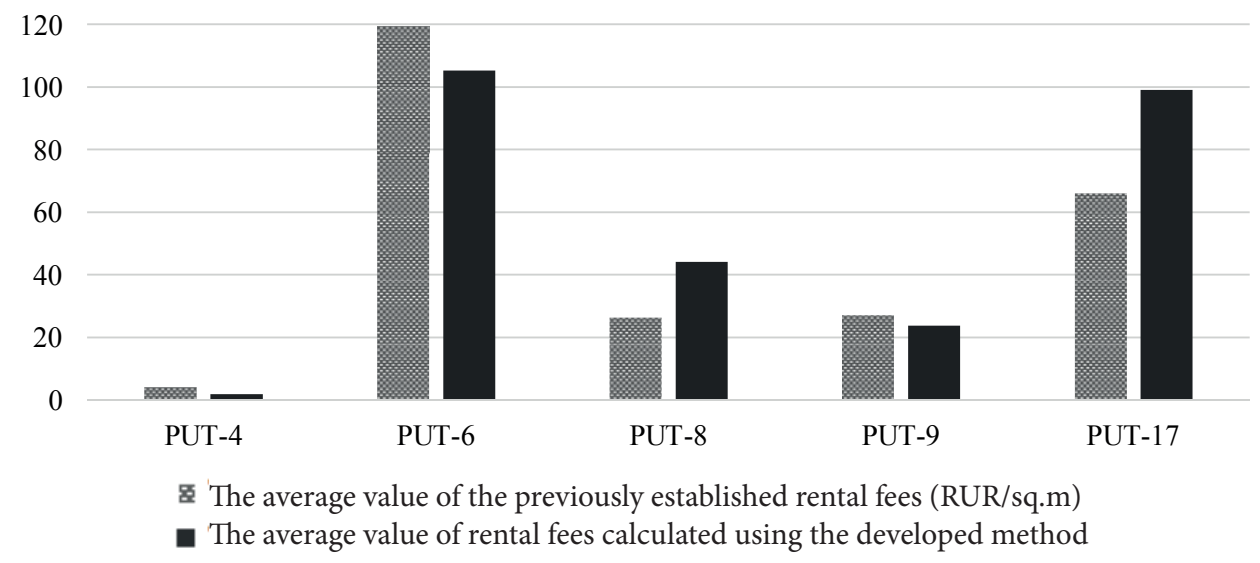

Source: own research based on calculations performed according to the author's methodology

Figure 3 shows the average rental fee for 1 sq. m. of land, depending on the permitted use types, calculated using the proposed methodology (Land Code of the Russian Federation 2001:4). From the diagram it can be seen that the largest rental fees will be inherent in the areas for trade and office development, that is, for the placement of profit-generating facilities (PUT-5, PUT-6, PUT-7 and PUT-17). A significantly smaller rental fee amount is typical of agricultural lands, lands for residential development, as well as for the placement of industrial facilities. The low rental fee value for lands for residential development is due to the non-commercial character of this type of activity. The absence of high rental fees for agriculture and industry is, in its turn, explained by the decline of these types of industries in Ivanovo, the lack of high profits, and the need for additional financing for further development (Current problems... 2018).

Figure 3. Comparison of rental fees for various plots of land in Ivanovo

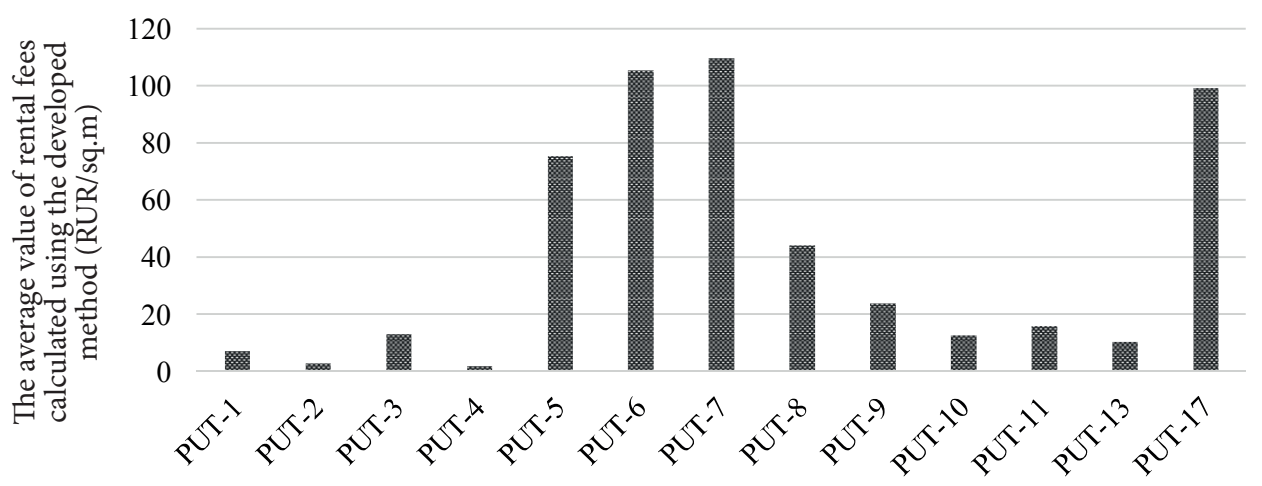

Source: own research based on calculations performed according to the author's methodology 
According to the results of the analysis, it can be concluded that the proposed methodology makes it possible to establish the lowered value of the corrective coefficients and, consequently, the rental fee amount for land of social significance that does not yield significant profits. Based on the example of calculating the corrective coefficients for land located in the city of Ivanovo, it is possible to note the increased amount of rental fees for land intended for the placement of trade facilities, public catering, consumer services, hotels, businesses, and commercial buildings. In turn, as can be seen from Figure 3, the fee for the use of land unrelated to commercialization (land for residential development, garden plots) is much lower, and this also applies to land where activities that require state social support for national economic development are carried out (land for industrial development and agriculture). This indicates that the methodology is consistent with the principle of taking into account the need to support socially significant activities. At the same time, there are increased rental fees amount due to the high value of corrective coefficients for land intended for the most profitable types of activities, which makes it possible to ensure the receipt of income from land-leasing by the municipalities' budgets.

\section{Conclusion}

The methodology to calculate the corrective coefficients involves accounting for the degree of profitability of activities carried out on the land, the relevant market segment development, and the availability of demand for the results of the activity, which corresponds to the principle of economic feasibility. Calculating both the degree of land use as well as the coefficient of investment attractiveness makes it possible to establish the lowered value of the corrective coefficient for socially significant types. The proposed methodology makes it possible to minimize the likelihood of violating the rights of any of the lessee groups, since the calculation is carried out solely based on such characteristics as the location of the facilities, the permitted land use type, and the potential profitability of activities carried out on land of a similar permitted use type. Thus, the proposed methodology correlates with the methodology for calculating the cadastral value, on the basis of which the calculation of the rental fee amount is then made. Consequently, it is possible to avoid contradictions in the calculation of various components of one value (the rental fee amount).

The proposed methodology is based on the calculation of coefficients for plots of land grouped according to major pricing parameters. Of course, the amount of rental fees calculated using this methodology will differ from the results calculated for each particular plot of land. However, for convergence of the results of group and individual calculations using the methodology proposed in the article, a greater number of parameters can be analyzed, on the basis of which grouping of lands is carried out. In practice, the process of increasing the number of land groups can develop gradually. Then, it will be associated with the distribution of labor and financial and time costs, which, on the one hand, will gradually lead to 
a higher level of detail in the groups of plots of land being evaluated. This will result in an increase in the accuracy of calculating the corrective coefficients and rental fees. On the other hand, it will facilitate the implementation of calculations with a much lower strain on municipal budgets compared with calculating rental fees for each piece of land separately.

The developed methodology was tested practically and endorsed in the process of calculating corrective coefficients for land in Ivanovo. Based on this methodology, municipalities can establish economically feasible coefficients necessary for the subsequent calculation of rental fees for land use.

\section{Bibliography}

Astrakhantseva I.A. (2016), The economically feasible methodology for calculation of corrective coefficients applied for determination of rental fees for land use [in:] New approaches in economy and management, Materials of the VI international scientific conference in Prague.

Balandina Y.V., Astrakhantseva I.A. (2016), Methodology for calculation of corrective coefficients applied for determination of rental fees for land use, "Audit and financial analysis" 16 (5).

Current problems of the social and economic development of Ivanovo region (2018), Public Chamber of Ivanovo Region, http://www.opiv.ru/examination/ doc/part1/ (accessed: 11.06.2018).

Dubina I.N. (2006), Mathematical foundations of empirical socio-economic research, Publishing house of Altai University, Barnaul.

Land Code of the Russian Federation (2001), Federal Law No. 136-FZ of 25 October 2001.

Leifer L.A. (2014), Directory of the real estate appraiser, Nizhny Novgorod.

Novitsky I.Yu., Dorofeev A.Yu., Golovanov V.I., Pavlova S.A., Fadeev A.S. (2015), Pricing parameters of the market for land and commercial real estate, "Internet-journal NAUKOVEDENIE", 7 (5).

On basic principles of rental fee calculation for land use that are in state ownership, and ownership of the federation and municipalities, and on the Rules for rental fee calculation for land use, the procedure, conditions and deadlines for the payment of rent for land owned by the Russian Federation (2009) Government of the Russian Federation Decree No. 582 of 16 July 2009.

Petrov V.I. (2007), Land evaluation, KNORUS, Moscow.

Tax Code of the Russian Federation (1998), Federal Law No. 146-FZ of 31 July 1998.

Telman, L.N. (2005), Property evaluation: Textbook for Higher Education Establishments, UNITY-DANA, Moscow.

Veig N.V. (2009), Evaluation of machines and equipment, SPbGUEF Publishing House, St. Petersburg. 


\section{Summary}

The authors propose a methodology to calculate corrective coefficients in the process of calculating rental fees for land use. Based on the analysis carried out, a list of factors affecting the value of the coefficients is presented: general economic and political factors, factors of the municipality's socio-economic status, factors of profitability, physical characteristics, and the geographical location of the plots of land. The authors propose a methodology to evaluate land use intensity. The authors calculated corrective coefficients used to determine rental fees for land use in Ivanovo, Russia. According to the results of the analysis, it can be concluded that the proposed methodology makes it possible to establish lower values of the corrective coefficients and, consequently, the rental fee amount for plots of land of social significance which do not yield significant profits. Based on the example of calculating corrective coefficients for land located in the city of Ivanovo, it is possible to note the increased amount of rental fees for land intended for the placement of trade facilities, public catering, consumer services, hotels, businesses and commercial buildings.

Keywords: rental fee, pricing factors, land, degree of land use

\section{Streszczenie}

\section{Metoda kalkulacji współczynników korygujących dla wyceny opłat czynszowych}

Autorzy proponują metodologię kalkulacji współczynników korygujących w procesie obliczania opłat czynszowych za wykorzystanie terenu. Na podstawie przeprowadzonej analizy stworzono listę kształtujących ich wartość czynników: ogólnoekonomicznych i politycznych, czynników związanych ze statusem społeczno-ekonomicznym obszaru miejskiego oraz z zyskownością, a także charakterystyk fizycznych i położenia geograficznego działek. Autorzy, proponujący metodę wyceny intensywności zagospodarowania terenów, obliczyli współczynniki korygujące dla wyceny czynszów w mieście Iwanowo w Rosji. Wyniki wskazują, że metoda ta pozwala na ustalenie niższych współczynników korygujących, a zatem - niższych wartości czynszu w przypadku działek o znaczeniu społecznym, które nie generują przy tym znaczących zysków. Te same obliczenia pozwalają odnotować zwiększoną wielkość opłat czynszowych związanych z terenami przeznaczonymi pod obiekty handlowe, użyteczności publicznej, usługi konsumenckie, hotele oraz budynki gospodarczo-biznesowe.

Słowa kluczowe: opłata czynszowa, determinanty wyceny, teren, stopień zagospodarowania terenu

JEL: C46, K25, R38 